\title{
Towards student wellness in the new teaching/learning process of Power Electronics
}

\author{
F. D. Trujillo-Aguilera, A. Pozo-Ruz \\ Departamento Tecnología Electrónica \\ Universidad de Málaga \\ Málaga, España (Spain) \\ \{fdtrujillo,apozo\}@uma.es
}

\author{
M. O. Martín-Graciani \\ Departamento Ingeniería Civil, de \\ Materiales y Fabricación \\ Universidad de Málaga \\ Málaga, España (Spain) \\ momartin@uma.es
}

\author{
J. Sánchez-Rodríguez \\ Departamento Didáctica y Organización \\ Escolar \\ Universidad de Málaga \\ Málaga, España (Spain) \\ josesanchez@uma.es
}

\begin{abstract}
Nowadays, university education has undergone a significant change to new models that encourage the active role of students in the learning process. Moreover, the European Higher Education Area means an important change in the teaching/learning process: it is necessary to involve more efficiently to the students and encourage their independent study and active participation. This new framework includes the increase in the development and use of new Information and Communication Technology in education and the analysis of the academic performance of students and their sensation of engagement and burnout. In the particular case of Power Electronics, a new teaching methodology, based on a set of new software multimedia interactive tools, is designed and developed to use for the teaching and learning of this subject. The evaluation process consists of several questionnaires: for both students and lecturers, in order to evaluate the quality of these multimedia interactive tools; and only for students, so as to check their stress levels. This subjective information will be complemented with a detailed analysis of the obtained marks of the students and with the sensation of engagement and burnout, measured in terms of academic stress. Finally, a comparison between theses students and the previous ones that could not use these new educational tools will determine the achievement of the foreseen objectives.
\end{abstract}

Keywords- Educational software evaluation; e-learning; Power Electronics; engagement; burnout; academic stress

\section{INTRODUCTION}

Information and Communication Technology (ICT) [1] is progressively including greater spaces in human beings' life, and education experiences its effect. In particular, educational software is necessary as an important resource in the teaching/learning process. Consequently, the importance of evaluation models increases in as much as the application of these instruments allows its effective evaluation and offers a greater guarantee of its use in these environments. New teaching methodology, based on a set of new software multimedia applications, is designed and developed to use for the teaching and learning of Power Electronics.

In the new European Higher Education Area (EHEA) [2] it is necessary to involve more efficiently to the students and encourage their independent study and active participation. This change has occurred at the same time as the increase in the development and use of new information technology in education: multimedia applications, simulation tools, educational platforms, among others; based on the spreading and frequent use of ICT.

This new increase of the student independence and the success in their career are very closer related to the engagement and attitude of the students. In order to obtain a more satisfaction feeling during the years of University, it is very important to analyze and study the student initial conditions (purposes, stress levels or expectation) and check these conditions during their stay in the University. And, of course, it is very important that the students can realize the constant concern of their lecturers.

\section{E-LEARNING}

One concept stemmed from the ICT environment is the elearning. E-learning comprises all forms of electronically supported learning and teaching. E-learning is essentially the computer and network-enabled transfer of skills and knowledge. E-learning offers a huge opportunity to learn and teach without being subject to limitations such as time or location [3].

Therefore, the traditional form of teaching in classroom can be complemented by the use of interactive systems based on computers. The use of these systems has significantly improved student learning and effectiveness, and teacher's educational work. The e-learning technologies [4] employed both inside and outside the classroom are increasingly influencing the nature of teaching/learning process. Web-based learning technologies are enabling powerful possibilities for learning activities outside the classroom, both in preparation for in-class activities and in following them up [5]. Of particular importance among these possibilities is the opportunity to address learners and individuals, assessing their strengths and weaknesses and adapting learning activities in response [6].

In the particular issue of Power Electronics, the lecturers of this subject found that students have difficulties to understand each operation of the converters, mainly due to their different performance depending on control parameters and load specified. Usually, it is very difficult to illustrate these concepts 
in a traditional classroom using static slides and blackboard [7]. In this work, the authors have developed a set of multimedia interactive tools for Power Electronics [8], gathered in an educational computer-aided platform, which can be used as online teaching tool. The platform takes advantages of the potential of Internet and multimedia tools for educational purposes, such as interactivity, dynamism, accessibility any place or any time.

The benefits of this computer-aided on-line platform for Power Electronics are: it combines, in a single platform, all interactive tools needed for a Power Electronics course; the platform is an open access web; it allows students to interact with the tool and organize their learning process; and finally, it is very useful for any student of this discipline as it covers all the basic aspects of Power Electronics (theory and laboratory) [9] [10].

\section{ENGAGEMENT AND BURNOUT}

In one hand, student engagement occurs when students make a psychological investment in learning [11]. It is increasingly seen as an indicator of successful classroom instruction, and as a valued outcome of the new teaching/learning process, above explained. Students are engaged when they are involved in their work, persist despite challenges and obstacles, and take visible delight in accomplishing their work. Student engagement also refers to a student's willingness, need, desire and compulsion to participate in, and be successful in, the learning process promoting higher level thinking for enduring understanding. Student engagement [12] requires that teachers actively seek to create the conditions that foster this reaction. Other steps include clear articulation of learning criteria with clear, immediate, and constructive feedback; show students the skills they need to be successful are within their grasp by clearly and systematically demonstrating these skills, and; demonstrate engagement in learning as a valuable aspect of their personalities.

On the other hand, burnout is a psychological term for the experience of long-term exhaustion and diminished interest [13]. A famous definition of burnout is a consideration about a general wearing out or alienation from the pressures of work or study [14]. How the stress is processed determines how much stress is felt and how close the student is to burnout. One student, for example, can experience few stressors, but be unable to process the stress well and thus experience burnout. Another student, however, can experience a significant amount of stressors, but process each well, and avoid burnout. How close a person is to a state of burnout can be determined through various tests [15].

\section{EVALUATION AND VALIDATION PHASES}

\section{A. Educational software evaluation}

The evaluation of the developed educational software represents an important task so as to allow and offers a greater guarantee of its correct use in educational environments. This evaluation has been widely analyzed and studied, providing several evaluation measures in technical and educational field.
From the pedagogical point of view, several software conditions must be considered regarding to the addresses (age, educational level), teaching (objectives, motivation, feedback, used methodology) or content (types, strategies). From the technical point of view, several conditions are studied: its usefulness (the ability to use the resource, access to the program, installation, operation, navigation), as well as the interface's characteristics (design of screens, disposition of menus, icons, images, color, graphics, animations) [16] [17].

For each new implemented interactive tool [8] [9] [10], four questionnaires have been implemented [18], for both students and lecturers, to validate these educational resources and their correct adaptation. Three of these questionnaires are approached for students; and the fourth questionnaire is addresses to some lecturers, defined in an expert group of five members.

The first questionnaire, called input questionnaire, for students, evaluates their initial situations in software skills and knowledge and their predispositions to work with the new educational tools. Once the new interactive tool has been developed, the students begin to use, and in parallel, this new tool has been evaluate by an expert group. The students validate several performance features of the tool through a satisfaction questionnaire; and the expert group studies similar features by means of a validation questionnaire. These two questionnaires analyze the interface features, the aesthetic features, the usefulness features, the technical features, the pedagogical features and some fostered skills and strategies.

Finally, an output questionnaire, again for students, tries to detect the general advantages of the use of the educational software tool for Power Electronics and the global opinion of the students related to their study time and the new used facilities.

\section{B. Engagement and Burnout evaluation}

The measurement of the engagement and burnout is related to the evaluation of the stress under several situations and conditions [19]. In the particular case of this study, academic stress is defined as that generated by the proper demands of an academic context, without the intervention of non-academic factors. The dimensions or evaluated academic stressors which will explain such stress (obligatory assignments, academic overload, perception of the teacher and perception of the subject, Power Electronics) will be susceptible of intervention in order to control the intensity with which they are perceived by the students, thus affecting two fundamental aspects during the development of their studies: their psychological wellbeing and their academic performance.

Three questionnaires are implemented in order to analyze the stress situations and their consequences in the student wellbeing [20]. The first questionnaire deals with several situations that can cause stress in the students. The other two questionnaires formulate several thinking and feelings that are conceived when students confront an anxiety and stress situations [19]. The anxiety experienced often becomes the cause of negative consequences which affect the students' mental health and academic performance. 


\section{RESUlts}

The results derived from all the questionnaires and presented in this section have been calculated by considering only the students who completed the questionnaires correctly, both concerning to the educational software and related to academic stress (engagement and burnout).

\section{A. Educational software}

Eight educational multimedia tools have been evaluated by means of the satisfaction and validation questionnaires, from 2004-2005 to 2007-2008 courses. Table I shows the number of analyzed questionnaires in this study.

TABLE I. NUMBER OF ANALYZED QUESTIONNAIRES

\begin{tabular}{|c|c|}
\hline QUESTIONNAIRES & NUMBER \\
\hline Input & 341 \\
\hline Satisfaction & 429 \\
\hline Validation & 40 \\
\hline Output & 464 \\
\hline
\end{tabular}

Table II shows the results of the input questionnaire analysis considering the most repeated positive responses of each of the ten open answers, gathered in function of similar aspects, in terms of percentage from the 2003-2004 course onward.

Tables III and IV presents the results of the satisfaction and validation questionnaires, in terms of mean values of all the answers related to the most important aspects (explained in section III) of each questionnaires analysis, being necessary to take into account the value of the standard deviation. The responses of each questionnaire are marked from 1 (entirely disagree) to 5 (entirely agree).

TABLE II. INPUT QUESTIONNAIRE ANALYSIS

\begin{tabular}{|c|c|}
\hline FEATURES & PERCENTAGE (\%) \\
\hline $\begin{array}{c}\text { Software skills and } \\
\text { knowledge }\end{array}$ & 73,4 \\
\hline $\begin{array}{c}\text { Predispositions to work } \\
\text { with the new } \\
\text { educational tools }\end{array}$ & 85,8 \\
\hline $\begin{array}{c}\text { Notions about the use of } \\
\text { these multimedia } \\
\text { interactive tools in } \\
\text { another subjects }\end{array}$ & 72,9 \\
\hline
\end{tabular}

TABLE III. SATISFACTION QUESTIONNAIRE ANALYSIS

\begin{tabular}{|c|c|c|}
\hline FEATURES & MEAN VALUE & STANDARD DEVIATION \\
\hline Interface & 4,56 & 0,24 \\
\hline Aesthetic & 4,21 & 0,17 \\
\hline Usefulness & 4,64 & 0.21 \\
\hline
\end{tabular}

TABLE IV. VALIDATION QUESTIONNAIRE ANALYSIS

\begin{tabular}{|c|c|c|}
\hline FEATURES & MEAN VALUE & STANDARD DEVIATION \\
\hline Interface & 4,35 & 0,34 \\
\hline Aesthetic & 4,28 & 0,27 \\
\hline Usefulness & 4,56 & 0,45 \\
\hline Technical & 4,44 & 0,48 \\
\hline Pedagogical & 4,61 & 0,14 \\
\hline Skills/Strategies & 4,68 & 0,19 \\
\hline
\end{tabular}

TABLE V. OUTPUT QUESTIONNAIRE ANALYSIS

\begin{tabular}{|c|c|}
\hline FEATURES & PERCENTAGE (\%) \\
\hline $\begin{array}{c}\text { General advantages of } \\
\text { the use of the } \\
\text { educational software } \\
\text { tool for Power } \\
\text { Electronics }\end{array}$ & 94,7 \\
\hline $\begin{array}{c}\text { Global opinion of the } \\
\text { students concerning } \\
\text { their study time }\end{array}$ & 91,4 \\
\hline $\begin{array}{c}\text { Global opinion of the } \\
\text { students concerning the } \\
\text { new used facilities }\end{array}$ & 92,3 \\
\hline
\end{tabular}

Finally, in table $\mathrm{V}$ is described the results of the output questionnaire analysis, taking into account, as in the input one, the most repeated positive responses of each open answers, gathered depending on similar aspects, in terms of percentage from the 2004-2005 course onward.

\section{B. Engagement and Burnout}

An amount of 410 questionnaires, related to academic stress, have been analyzed in this study. The examined variables encompass aspects about the student work overload; public discussion; exams; teaching methodological deficiency; relationships in the academic environment; or low academic esteem.

Some general conclusions can be drawn. The results showed that high levels of dedication and vigor are related to the development of the interactive multimedia tools. As far as the improvement of students' learning quality and their psychological comfort are concerned, these findings reveal the value of developing emotional abilities in the classroom as a buffer factor of academic stress elements and as an important vehicle to increase students' dedication towards learning.

Furthermore, the results showed that although the stress level suffers by the students does not directly influence their academic results, there is a correlation with some problem situations. And the students are more motivated in the subject study in accordance with the total implementation of the educational software.

Finally, the study shows [21] that women students suffer high levels of academic stress than men students. This result can be caused by the physiological differences between men and women. And it has been demonstrated that in another environment, like Health Sciences, the results are similar [22]. 


\section{CONCLUSIONS AND FORTHCOMING WORKS}

In this paper we have discussed about the importance of the evaluation of educational software and the student engagement and burnout in order to improve a quality atmosphere and to guarantee the correct use of the educational software according to the initial goal. In the particular case of the set of new implemented interactive tools for teaching and learning of Power Electronics, the developed questionnaires have demonstrate the accurate and correct use of the educational tools in and out of classroom and the improving of the wellbeing sensation of students in the subject.

In addition with the study described in this paper, and with the idea in mind of complementing the obtained results, it is very interesting to perform a detailed study of the obtained marks of the students and compared them with the previous students that could not use these new educational tools.

\section{REFERENCES}

[1] G. Beauchamp and S. Kennewell, "Interactivity in the classroom and its impact on learning", Computers and Education, vol. 54(3), pp. 759-766, April 2010.

[2] The European Higher Education Area, Bologna Declaration, 1999.

[3] T. Martín Blas and A. Serrano-Fernández, "The role of new technologies in the learning process: Moodle as a teaching tool in Physics", Computers and Education, vol. 52(1), pp. 35-44, January 2009.

[4] G. Hwang, "A tutoring strategy supporting system for distance learning on computer networks", IEEE Transactions on Education, vol. 41(4), pp. 333-343, 1998.

[5] G. Bengu and W. Swart, "A computer-aided, total quality approach to manufacturing education in engineering", IEEE Transactions on Education, vol. 39(3), pp. 415-422, 1996.

[6] J. E. Stephenson, C. Brown, and D. K. Griffin, "Electronic delivery of lectures in the university environment: an empirical comparison of three delivery styles", Computers and Education, vol. 50, pp. 640-651, April 2008.

[7] A. A. Nogueiras-Meléndez, A. Lago-Ferreiro, A. Montero, A. Otero, L. E. Eguizábal, and C. Martínez-Peñalver, C., "A course on dc-dc converters towards the ECTS using the B-learning methodology", IEEE International Conference on E-Learning in Industrial Electronics, pp. 13$18,2009$.

[8] A. Pozo-Ruz and F. D. Trujillo, "A web-based tool for a Power Electronics course", II Conferencia Internacional en Fomento e Innovación con Nuevas Tecnologías en la Docencia de la Ingeniería, 2011.

[9] M. A. Callejón-Giménez, J. García-Romero, A. Pozo-Ruz, and F. D. Trujillo-Aguilera, "Plataforma virtual didáctica de Electrónica de Potencia acorde a los paradigmas de los ECTS", 17 Congreso Universitaria de Innovación Educativa en Enseñanzas Técnicas, 2007.

[10] A. Pozo-Ruz, M. J. Morón-Fernández, J. R. Luque-Giráldez, F. D. Trujillo-Aguilera, and G. Torcello, "Plataforma virtual interactiva para la docencia del Laboratorio de Electrónica de Potencia", XI Simposio Nacional de Tecnologías de la Información y las Comunicaciones en la Educación, 2010.

[11] F. Newmann, "Student Engagement and Achievement in American Secondary Schools", Teachers College Press, pp. 2-3, 1992.

[12] A. Caruana, E. Martínez, A. Reig, and J. Merino, "Evaluación del estrés en estudiantes de medicina", Ansiedad y Estrés, vol. 5(1), pp. 79-97, 1999.

[13] C. Maslach, "Burnout: the cost of caring", Englewood Cliffs, New Jersey: Prentice-Hall, 1982.

[14] I. J. Deary, R. Watson, and R. Hogston, "A longitudinal cohort study of burnout and attrition in nursing students", Journal of Advanced Nursing, vol. 43(1), pp. 71-81, 2003.
[15] R. H. Zabel and M. K. Zabel, "Burnout among special education teachers and perception of support", Journal of Special Education Leadership, vol. 15, pp. 67-73, 2002.

[16] E. Navarro, "Evaluación de materiales multimedia. Proyecto SAMIAL", Comunicación y Pedagogía, vol. 157, pp. 36-39, 1998.

[17] Michigan Virtual University, "Standard Quality on-line courses", Available, 2002: http://ideos.mivu.org/standards

[18] F. D. Trujillo-Aguilera, A. Pozo-Ruz, and J. Sánchez-Rodríguez, "On the evaluation stage for new Power Electronics multimedia interactive tools. The importance of the questionnaires", IEEE Global Engineering Education Conference, 2012.

[19] R. J. Díaz, C. R. Glass, D. B. Arnkoff, and M. Tanofsky-Kraff, "Cognition, anxiety, and prediction of performance in 1st-year law students", Journal of Educational Psychology, vol. 93(2), pp, 420-429, 2001.

[20] R. Cabanach, A. Valle, I. Piñeiro, S. Rodríguez, and M. García, "Cuestionario de estrés académico: construcción de una escala de medida", V Congreso Internacional de Psicología y Educación: los retos de futuro, 2008.

[21] M. O. Martín-Graciani and F. D. Trujillo-Aguilera, "Bachelor student academic stress in industrial engineering", III Jornadas sobre Innovación Docente y Adaptación al EEES en las Titulaciones Técnicas, 2012.

[22] M. J. Casuso, "Estudio del estrés, engagement y rendimiento académico en estudiantes universitarios de Ciencias de la Salud", Málaga: SPICUM, 2011. 